\title{
A NUMERICAL MODEL ON GEOSYNTHETIC REINFORCED PILE SUPPORTED EMBANKMENTS
}

\author{
Eren BALABAN ${ }^{1,}$, , Mehmet İnanç ONUR ${ }^{2}$ \\ ${ }^{1}$ Department of Transport Structures, Jan Perner Transport Faculty, University of Pardubice, Pardubice, Czechia \\ ${ }^{2}$ Department of Civil Engineering, Faculty of Engineering, Anadolu University, Eskişehir, Turkey
}

\begin{abstract}
Reinforced pile embankments were started to be used more commonly because they allow fast construction of highways. When geosynthetics are adopted to piled fills, this kind of structures are then called as geosynthetic reinforced piled structures. When the geosynthetics are used, area of pile caps is reduced because geosynthetic transfers fill load to piles by its membrane effect. In this study, effect of multi - layer reinforcement is investigated using 2D finite element method. For this purpose, settlements, pressures, excess pore water pressures and horizontal displacements are analyzed. Results showed that using two and three layers of reinforcement significantly decreases settlements on foundation soil and embankment surface. Placement of an additional layer has great effect on settlements, pressures, excess pore water pressure and horizontal displacements. It is also found out that, two layers of reinforcement is more effective when only settlements are considered.
\end{abstract}

Keywords: Geosynthetic reinforced pile supported embankment, Settlement, Pile, Stress distribution

\section{INTRODUCTION}

Increase of population causes increasing demands in infrastructure investments. Those infrastructure investments can be listed as a construction of new highways, railroads, airports or widening existing roads. However, embankment construction can expose hard situations for a geotechnical engineer. These situations can be counted as high compressibility and high settlements with time due to low undrained strength of soft soil layer. These undesirable conditions can be overcome by traditional ground improvement methods. These methods can be listed as preloading or staged construction, addition of vertical drains, use of lightweight fill, excavation of unsuitable layer by replacing it with suitable fill material and reducing the slope of the embankment [1]. If a project might have a tight schedule, engineers may not have enough time to apply traditional ground improvement methods. Usage of the piled embankment can be the initial solution because embankment loads can be transferred to firm layer. However, this solution requires large pile caps which is uneconomical and also time consuming. In this case, replacing expensive and large pile caps with cheaper geosynthetic can be a good idea. This kind of embankments are called as geosynthetic reinforced piled embankment. Since the loads are transferred to firm layer, settlements during construction and post construction are significantly reduced. Differential settlements are also decreased. Lateral movement of the embankment is limited. Less maintenance is required and pile cap area is also reduced. Due to these outcomes, embankment construction becomes more economical and less time consuming.

Fill loads transferred to piles firstly and then to firm layers. Stress transfer mechanism from fill to piles is called as soil arching. Terzaghi explained soil arching as, when two adjacent soil exists and one yields, shear bands forms between yielding and the adjacent one. Shearing reduces stress over the yielding soil and transfers it to adjacent soil [1].

*Corresponding Author: erenb@anadolu.edu.tr

Receiving Date: 08 January 2018 Publishing Date: 29 June 2018 
In the study of Han and Gabr, difference between coverage areas of piled fills and geosynthetic reinforced piled fills can be seen. Their study shows that, maximum settlement decreased due to the stiffness of geosynthetic and piles are increased. According to this study, tension on geosynthetic depends on the height of the embankment, stiffness of geosynthetic and elastic modulus of piles [2]. Formation of soil arching and the load transfer mechanism from highway embankment to soil and piles via geosynthetics is depicted by Van Eekelen et al. Their experiments showed that higher fill friction angle develops better arching during consolidation. It is also found out that, when two geosynthetic layers are used with a 5-cm distance, soil arching develops slower, however, it remains more stable once its formed [3]. Van Eekelen et al. conducted experimental study to determine the loading parts separately and factors that are affecting soil arching and load distribution. In the second part of their study, experimental results are compared with analytical design guide. Shortcomings of analytical design guideline is identified and necessary modifications are suggested [4]. Bhasi and Rajagopal performed a parametric study to show effects of pile length on skin friction and axial load of pile, settlement of embankment, soil pressure between embankment and foundation soil. Results are also compared with British Design Guideline BS8006. Results shows that, when soil settles more than pile, negative skin friction occurs. Researchers also showed that, pressure on foundation soil increased as fill height increased, which is contrarily behavior to British standard, BS8006. Due to this contradiction, researchers proposed a modification to British standard [5]. Lai et al. demonstrated soil arching within geogrid-reinforced and unreinforced pile supported embankment by using discrete element method. Their study showed three stages of soil arching with respect to surcharge loads and shows instability. They also show that, transition between those stages depend on location of piles and their center to center distance. Researchers also concludes that subsoil stiffness and embankment's particle size has effect on arching behavior of soil [6]. Xing et al. conducted large scale tests for a pile supported earth platform with geogrid and without geogrid. Results from the tests with geogrid are used to compare analytical results of EBGEO. Researchers found out that, pile axial loads are equal or up to threshold value of embankment load. Their study also proves that, when reinforcement is involved, lower negative skin friction is observed on pile, and stress is concentrated on the edges of pile caps. Those results are attributed to effect of soil arching in reinforced case. At the end of their study, researchers concluded that experimental results are compatible with EBGEO, but stated that EBGEO is only valid for one layer of reinforcement [7].

In the study of Huang and Han, performance of a reinforced deep mixed column supported embankment was evaluated numerically. Researchers concluded that, properties of soft soil and deep mix columns affect post construction settlement, maximum differential settlement, distortion, tension over geosynthetic and degree of consolidation. Study showed that, differential settlement is influenced mostly by column spacing. Effect of soft soil stiffness is more pronounced in post construction settlement [8]. Same researchers conducted also 3D numerical analysis of reinforced deep mix column supported embankment. Researchers concluded that, settlement on crest is much lower and important than the settlement on the base. Researchers also find out that, stress acting over reinforcement decreases as consolidation settlement increases due to lateral rebound of soft soil [9]. Reinforcements are usually spread over the pile caps. However, the research conducted by Zhang et al. introduces new way of spreading geosynthetic. Researchers provided connection way between pile caps and geosynthetic that allows connection of geosynthetic rigidly to pile caps. Researchers also conducted parametric study to find out effects of tensile stiffness of reinforcement, pile spacing, elastic modulus of soft clay, pile and pile width. Proposed new connection method decreases settlement, lateral displacement and excess pore water pressure. However, larger tensile stress is measured on geosynthetic. Tensile stress increases during post construction phase [10]. Liu and Rowe investigated the effect of geosynthetic and change of soft soil's hydraulic conductivity during construction. They also considered effect of rate of construction, column stiffness, spacing and different soil profiles. Researchers found out that, viscous nature of reinforcement does not have influence on creation of pore water pressure. Dissipation rate of excess pore water pressure was higher in case of constant hydraulic conductivity. However, total settlement is lower because soil develops its strength earlier [11]. Zhang et al. developed an analytical 
model to calculate the amount of settlement of a reinforced pile supported embankment. The developed method is based on Winkler's foundation. Proposed method is compared with existing data. It is seen that proposed new method can predict the settlement on the center of the embankment. When the pile stiffness and interface resistances between pile and soil are increased, settlement decreases [12]. Since there are many design methods related to reinforced pile supported embankments in the literature, Ariyarathne and Liyanapathirana reviewed several design methods and compared them with 3D and 2D numerical analysis. Comparison of numerical analysis and design methods shows that, Guido, Low and Abusharar's methods' under predicts stress reduction ratio while these methods perfectly predict geosynthetic stress and strain. When pile efficiency is considered, it is seen that Terzaghi, Hewlett and Rondolf, BS8006 and Kempfert methods give inconsistent results while Guido, Low and Abusharar method highly overpredicts with respect to numerical methods [13].

Lu and Miao developed a new method to calculate stresses on pile cap and geosynthetic. During their study, authors considered membrane effect of geosynthetic and strength of subsoil. Results from proposed method comply with the field data. Proposed method also improves some of the existing design methods by replacing the calculated ratio of piles and subsoil [14]. Ghosh et al. proposed a mechanical model by using Timoshenko's beam theory. Developed model applied to one-layer geosynthetic and as well as two-layer geosynthetics cases. At the end of their study, researchers compared computed results for one-layer and two-layer geosynthetic produced by proposed new method. This study reveals that, using two-layer weaker reinforcements decreases settlements more than using one-layer stronger reinforcement [15]. Lehn et al. carried out a three-dimensional numerical study by using finite element method in order to determine influence of cyclic loading in the arching mechanism. Researchers concluded that, soil arch's shape changes during initial cycles but later it becomes stable. [16]. Van Eekelen presented results from the new version of Dutch Design Guide. She also stressed out limitations of the new design guideline [17]. Van Eekelen and Venmans compared traditional way of constructing embankment and reinforced pile supported embankment by means of economic aspects and geotechnical risks. The study concluded that, construction of geosynthetic reinforced piled embankments needs almost same budget but, when geotechnical risks and maintenance costs are taken into consideration, it is more likely to prefer to construct geosynthetic reinforced piled embankments [18]. Zhou et al. investigated soil arching mechanism on a railroad embankment using finite element method. Researchers observed highest cap load and highest arch height on the central pile cap [19]. Liu et al. observed behavior of well-equipped reinforced pile supported embankment. Their study consisted of measuring settlements of piles and soil surface, lateral displacement, forces acting on piles and geosynthetic. They concluded that, when the height of embankment is over $2.4 \mathrm{~m}$, predictions of stress reduction ratio based on the methods proposed by Russel, Pierpoint, Hwelett and Randolph are consistent with measured and calculated values. However, when the embankment height is lower than $2.4 \mathrm{~m}$, method of Russell and Pierpoint gives consistent predictions with the field measurements [20].

Rui et al. conducted experiments in order to observe development of soil arch and its type. They considered different pile dimensions, different trapdoor width and different sand granulometry. Symmetrical triangle shear bands are formed at the initial stages of settlement. After fully formation of symmetrical triangular shear bands, different type of shear bands starts to be observed depending on height of embankment, distance between piles, and dimensions of pile caps [21]. Van Eekelen et al. analyzed BS8006 and revealed some disadvantages of BS8006 and necessary modifications are proposed. Comparison between field data and BS8006 shows inconsistency for calculation of force on geosynthetic. But, calculations made after proposed modifications produced better results and shortcomings [22]. Van Eekelen et al. carried out a research consisted of two stages to measure and calculate forces transferred to piles, geosynthetics and subsoil. At the first stage, researchers separately measured forces from experiments. They also conducted a parametric study to reveal possible effects of different geosynthetic types, usage of double layer biaxial geogrid without fill between and stiffness of geosynthetic. Experimental results are compared with analytical results computed by EBGEO. Due to the difference, some modifications are proposed to EBGEO in order to design reinforced piled 
embankments more accurately $[23,24]$. Van Eekelen et al. compared several analytical methods with several field tests and several model tests to validate analytical methods by comparing geosynthetic strain. Researchers tried different analytical methods according to arching model methods. They concluded that, concentric arch model gives better result for the calculation of geosynthetic strain [25].

It can be easily evaluated that, some of the researchers focused on determining forces and strains on reinforced pile embankments and geosynthetics. Those studies generally concentrate on laboratory modeling and developing analytical models. Some other researchers are focused on estimating forces and strains by using finite element or finite difference methods and then conducting parametric study to reveal effects of selected variables. However, there are only a few articles where more than one geosynthetic layer and their placement in working platform. In this study, two and three layers of geosynthetic are placed inside an embankment to reveal their effects.

\section{MATERIAL AND METHOD}

Liu et al.'s research [20] is selected as a base case for this study, because the study gives very detailed information about forces, settlements, excess pore water pressure and lateral displacements. Selected study concerns about construction of $5.6 \mathrm{~m}$ height and a side slope of $1 \mathrm{~V}: 1.5 \mathrm{H}$. Construction period is given as 55 days. Soil profile consists of $1.5 \mathrm{~m}$ granular fill, $2.3 \mathrm{~m}$ silty clay, $10.2 \mathrm{~m}$ soft silty clay, $2 \mathrm{~m}$ medium silty clay and $9 \mathrm{~m}$ sandy silt.

The measurement points for each case can be seen at Figure 1 [20]. This figure is taken from the reference study. Placement of settlement gages S1, S2, S3 and S4, pore water pressure piezometers P1 and P2, pile A, and inclinometer I1 can be seen clearly from the figure. Placement of earth pressure cells also given in Figure 1 (b) as a plan. E9 and E10 is located on pile A, while other pressure cells are located around pile A. Detailed information about instruments are provided in the next paragraph. Piles are constructed in square pattern.

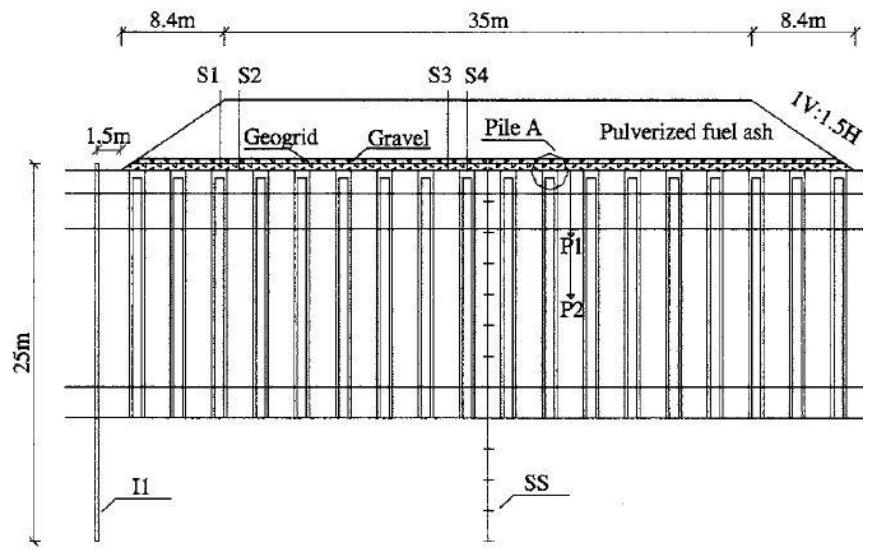

(a)

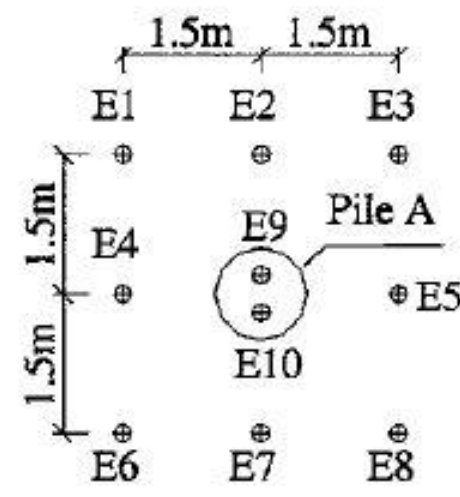

(b)

Figure 1. (a) Cross-section of modelled embankment and measurement points; (b) Detailed view of pressure cells placed near pile A. [20]

In order to observe embankment behavior, earth pressure cells and surface settlement plates are installed after construction of piles. Those pressures cells are named as E1, E2, E3, E4, E5, E6, E7, E8, E9 and E10. Earth pressure cells E1-E8 are capable of measuring maximum $0.3 \mathrm{MPa}$, while E9 and E10 can measure pressures up to $1 \mathrm{MPa}$. Four surface settlement gauges are also installed and named as S1, S2, S3 and S4. Two of the settlement gauges S1 and S4, are located over pile head while the other two are located on the subsoil. Vertical inclinometer is installed at distance of 1.5 meter from the embankment toe to measure lateral displacement. Two pore water pressure piezometers are installed at a depth of 4- 
meter and 8-meter midway between two piles near to the center of the embankment. Placement of all instruments can be seen on Figure 1. Measured pressures and settlements during and after construction is given in Table 1 for E4, E9, S1, S2, S3 and S4. Reinforcement that is used in the construction of embankment is chosen as biaxial polypropylene geogrid. The tensile stiffness of the geogrid is given as $90 \mathrm{kN} / \mathrm{m}$. Maximum allowable tensile strain of the geogrid is equal to 8\%. Tensile stiffness of the geogrid is given as $1180 \mathrm{kN} / \mathrm{m}$.

In this study, settlement of piles and embankment, pressures on piles and subsoil, development and dissipation of excess pore water pressure, and horizontal displacement is investigated based on using multiple layer of reinforcement. For this purpose, models are analyzed by using finite element code Plaxis. Material models and parameters used in present study is given in Table 2. Some of the parameters are missing in the Liu et al.'s article. Those parameters are listed as coefficient of permeability of embankment, gravel, coarse grained fill, coefficient of permeability at horizontal direction, angle of friction of soil layers, $\lambda^{*}, \kappa^{*}$ and initial void ratio $\mathrm{e}_{0}$ and elasticity modulus of sandy silt for material model hardening soil model. All the missing permeability coefficients are determined from the relationship given by Das [26]. Plane strain angle of frictions are found by the formula used also by Suliman B.A. Mohamed et al [27].

Table 1. Measured settlements and pressures on the field

\begin{tabular}{lcc}
\hline \multicolumn{3}{c}{ Experiment } \\
\hline S1 $(\mathrm{mm})$ & $55^{\text {th }}$ day & $180^{\text {th }}$ day \\
S2 $(\mathrm{mm})$ & 9 & 14.3 \\
S3 $(\mathrm{mm})$ & 41 & 65 \\
S4 $(\mathrm{mm})$ & 63 & 87 \\
E4 $(\mathrm{kPa})$ & 31.4 & 19 \\
E9 $(\mathrm{kPa})$ & 583.6 & 710 \\
\hline & &
\end{tabular}

Angle of frictions of other materials and $\lambda^{*}$ and $\kappa^{*}$ can be found by using formulas given below. Those formulas can be found in Plaxis user's manual [28].

$$
M=\frac{6 \sin \varphi}{3-\sin \varphi}
$$

Table 2. Material models and parameters used in finite element modelling

\begin{tabular}{|c|c|c|c|c|c|c|c|c|c|c|}
\hline Material & Model & c (kPa) & $\phi^{0}$ & $\begin{array}{c}\mathbf{E} \\
(\mathbf{k P a})\end{array}$ & $\mathbf{v}$ & $\lambda^{*}$ & $\kappa^{*}$ & $\mathbf{e}_{0}$ & $\begin{array}{c}\mathbf{k}_{\mathbf{x}} \\
(\mathbf{m} / \mathbf{d a y})\end{array}$ & $\begin{array}{c}\mathbf{k}_{\mathbf{y}} \\
\text { (m/day) }\end{array}$ \\
\hline Embankment & $\begin{array}{c}\text { Mohr - } \\
\text { Coulomb }\end{array}$ & 11 & 28 & 20000 & 0.3 & - & - & - & 129.6 & 86.4 \\
\hline Gravel & $\begin{array}{c}\text { Mohr - } \\
\text { Coulomb }\end{array}$ & 11 & 43 & 20000 & 0.3 & - & - & - & 129.6 & 86.4 \\
\hline $\begin{array}{c}\text { Coarse- } \\
\text { Grained Fill }\end{array}$ & $\begin{array}{c}\text { Mohr - } \\
\text { Coulomb }\end{array}$ & 17 & 25 & 7000 & 0.3 & - & - & - & 129.6 & 86.4 \\
\hline Silty Clay & $\begin{array}{l}\text { Soft Soil } \\
\text { Model }\end{array}$ & 1 & 28 & - & 0.35 & 0.036 & 0.00727 & 0.65 & $1.296 * 10^{-4}$ & $8.64 * 10^{-4}$ \\
\hline $\begin{array}{l}\text { Soft Silty } \\
\text { Clay }\end{array}$ & $\begin{array}{c}\text { Soft Soil } \\
\text { Model }\end{array}$ & 1 & $\begin{array}{l}19 \\
.3\end{array}$ & - & 0.35 & 0.069 & 0.014 & 1.17 & $6.48 * 10^{-4}$ & $4.32 * 10^{-4}$ \\
\hline $\begin{array}{l}\text { Medium Silty } \\
\text { Clay }\end{array}$ & $\begin{array}{c}\text { Soft Soil } \\
\text { Model }\end{array}$ & 1 & $\begin{array}{l}24 \\
.5\end{array}$ & - & 0.35 & 0.03 & 0.006031 & 0.66 & $6.48 * 10^{-4}$ & $4.32 * 10^{-4}$ \\
\hline Sandy Silt & $\begin{array}{l}\text { Hardening } \\
\text { Soil Model }\end{array}$ & 1 & $\begin{array}{l}9 . \\
3\end{array}$ & 79710 & 0.35 & - & - & 0.78 & $6.48 * 10^{-4}$ & $4.32 * 10^{-4}$ \\
\hline
\end{tabular}




$$
\begin{aligned}
\lambda^{*} & =\frac{\lambda}{1+e_{0}} \\
\kappa^{*} & =\frac{\kappa}{1+e_{0}}
\end{aligned}
$$

Initial void ratio is calculated by the formula given on Liu's study. This formula uses undrained cohesion, critical state line, cam-clay model parameters and void ratio at unit pressure. These parameters are found in Liu's study.

$$
\mathbf{e}_{0}=\left[(1+\mathbf{e})-(\lambda-\kappa) \ln 2-\lambda \ln \left(\frac{2 c_{\mathrm{u}}}{\mathrm{M}}\right)\right]-1
$$

Elasticity modulus of sandy silt is calculated by the formula given below by Stein Sturr [29].

$$
E^{50}=\frac{15000 c_{u}}{I_{p} \%}
$$

A cross-section of a reinforced pile embankment is modelled on Plaxis after determination of all necessary material model parameters. Selected Plaxis models of 2-layer and 3-layer of geosynthetics are given in Figure 2. Finite element modelling consisted of 55 days of construction. Construction of embankment is completed by nine lifts in the finite element analysis just like the reference study. This principle is applied in all the other finite element analysis. After that, another step is defined, which prolongs the analysis time to 180 days so that post construction results can be compared with the field results. After that, for the aims of this study and better understanding of embankment behavior, analysis time is prolonged to 1000 days. Since, settlements, excess pore water pressure and dissipation are important, consolidation type of analysis is selected. Consolidation analysis provides more accurate results and more data in the given interval. Total time of solution is specified as 1000 days from the beginning of the construction. When the results of the finite element model are close enough to field measurements, parametric study regarding number and placement of reinforcement is conducted. Placement of reinforcement is given in Table 2 for both 2 and 3 layers of reinforcement.

Table 3. Placement of 2nd and 3rd layer of reinforcement inside embankment

\begin{tabular}{ccccc}
\hline $\begin{array}{c}\text { Number of } \\
\text { Reinforcement }\end{array}$ & Case & 1st Reinforcement(m) & $\begin{array}{c}\text { 2nd } \\
\text { Reinforcement(m) }\end{array}$ & $\begin{array}{c}\text { 3rd } \\
\text { Reinforcement(m) }\end{array}$ \\
\hline 2 & 1 & 0 & 0.25 & - \\
2 & 2 & 0.25 & 0.5 & - \\
2 & 3 & 0 & 0.5 & - \\
2 & 4 & 0.25 & 2.42 & - \\
2 & 5 & 0.25 & 3.70 & - \\
2 & 6 & 0.25 & 4.98 & 0.5 \\
3 & 1 & 0 & 0.25 & 1.78 \\
3 & 2 & 0.25 & 1.14 & 2.42 \\
3 & 3 & 0.25 & 1.78 & 3.70 \\
\hline
\end{tabular}

It should be noted that, one reinforcement is always left inside the working platform of embankment due to soil arching mechanism.

\section{RESULTS}

Field measurements are compared with model results for both 55 days and 180 days to validate finite element model. It is seen that, the lowest difference for settlement is observed as $1.35 \%, 2.30 \%, 3.80 \%$ at E2, E3 and E4. The highest difference between finite element method and test measurements are obtained as $16.22 \%$ at E9. These results show that, there is a relatively good agreement between finite 
element modeling and test measurements. After proving finite element method, new model analysis are made regarding number of layers. Results for 2-layer reinforcement is given in section 3.1 and results for 3-layer reinforcement is given in section 3.2. Deformed shape of the finite element model is provided in the Figure 3 given below for both 2-layer and 3-layer of geosynthetic as an example.

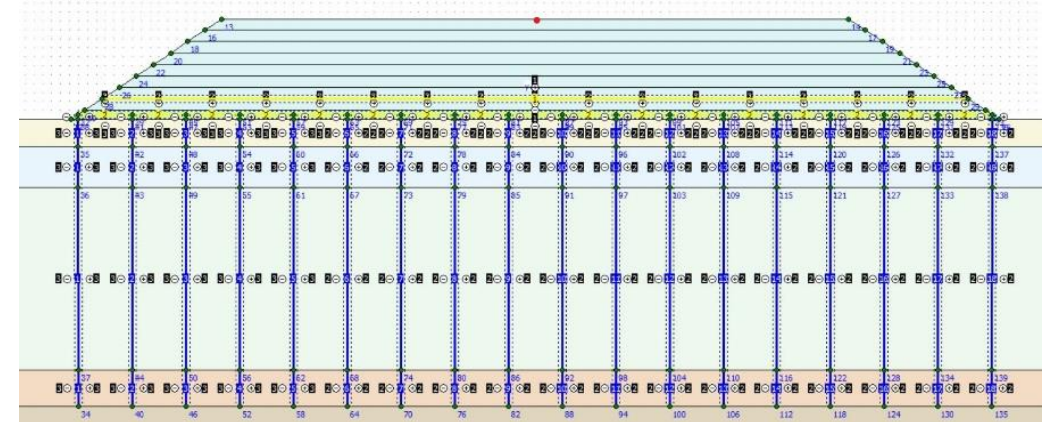

(a)

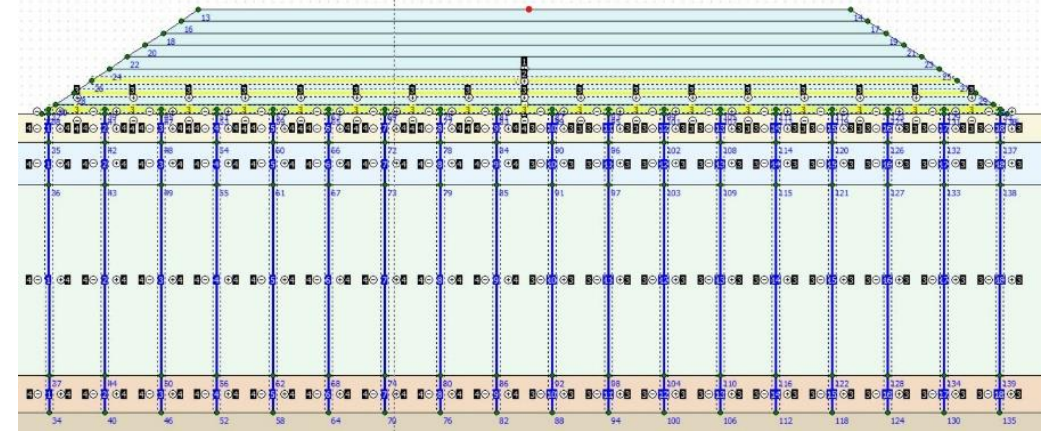

(b)

Figure 2. Finite element model for (a) 2 layers and (b) 3 layers geosynthetic arrangement.

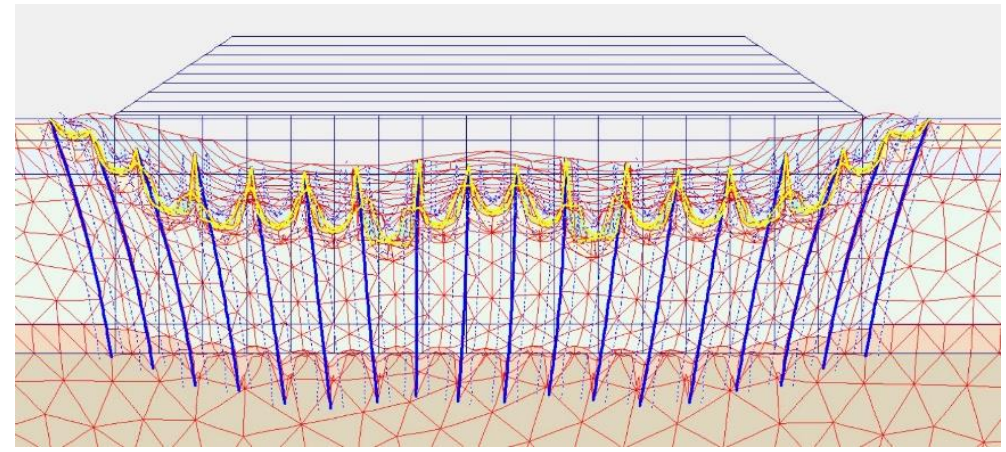

(a)

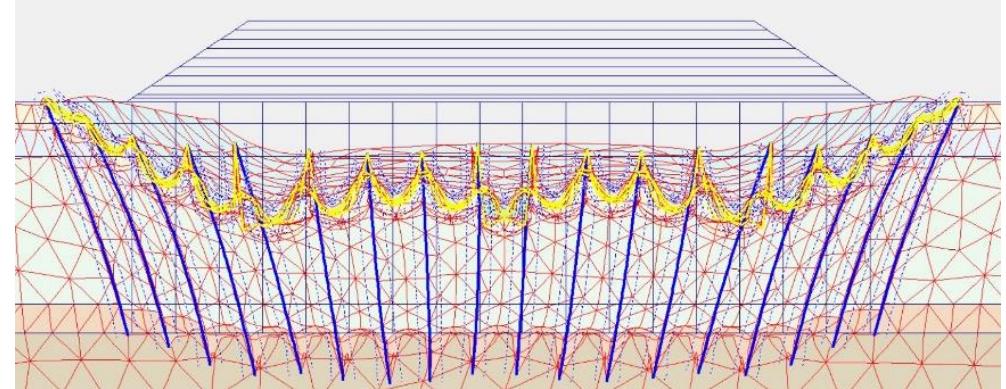

(b) 
Balaban and Onur / Anadolu Univ. J. of Sci. and Technology A-Appl. Sci. and Eng. 19(2)-2018

Figure 3. Deformed shape of (a) 2 geosynthetic layer; (b) 3 geosynthetic layer

\subsection{Effect of 2 Layers Reinforcement}

\subsubsection{Settlements}

Settlements determined at S1, S2, S3, S4 as well as on embankment surface will be considered. Settlements calculated for one-layer reinforcement, 1000 days after beginning of construction at S1, S2, $\mathrm{S} 3$ and $\mathrm{S} 4$ gauges are $25.03 \mathrm{~mm}, 56.33 \mathrm{~mm}, 89.14 \mathrm{~mm}, 31.44 \mathrm{~mm}$ respectively. Settlement behavior of those point can be seen at Figure 4. Calculated lowest settlements are \%16.90, \%14.68, \%17.78 and $\% 15.71$ lower than reference case for S1, S2, S3 and S4. However, it should be noted that, settlement calculated for $\mathrm{S} 4$ for third case is $27.01 \mathrm{~mm}$ which only $0.5 \mathrm{~mm}$ higher than first case.

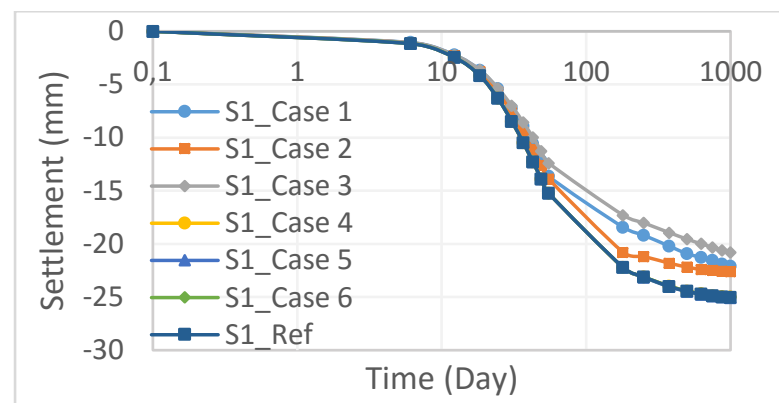

(a)

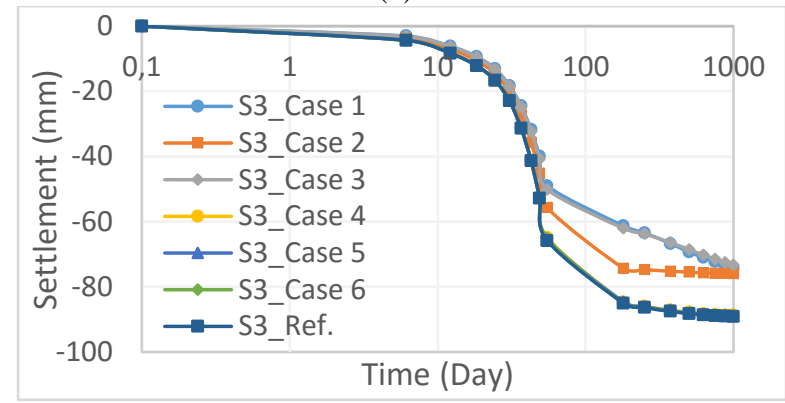

(c)

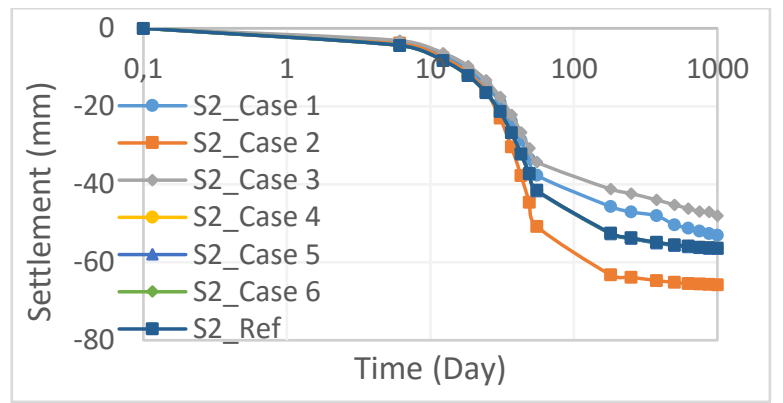

(b)

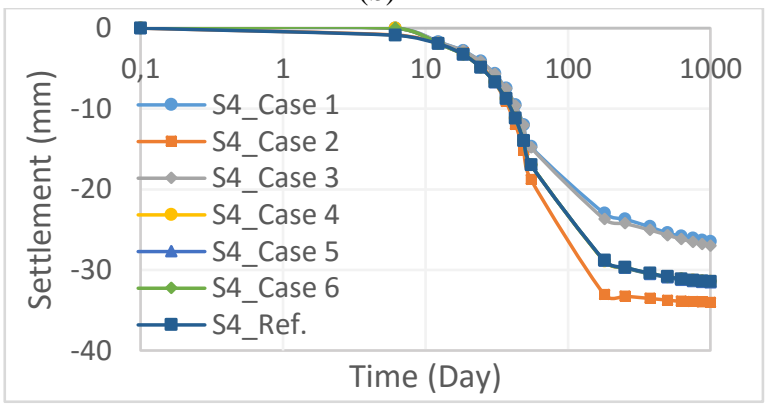

(d)

Figure 4. Calculated settlements for two-layer reinforcement: (a) S1, (b) S2, (c) S3, (d) S4

Settlements on the embankment surface is important because the serviceability of the highway. Lowest settlement on the center of embankment surface is calculated as $78.06 \mathrm{~mm}$ for the second case. This value is $21.80 \%$ lower than the reference case. In Figure 5, settlement change with time can be seen for all cases considered in this study. This graphic begins from 55th day because this part of the embankment is constructed on that day.

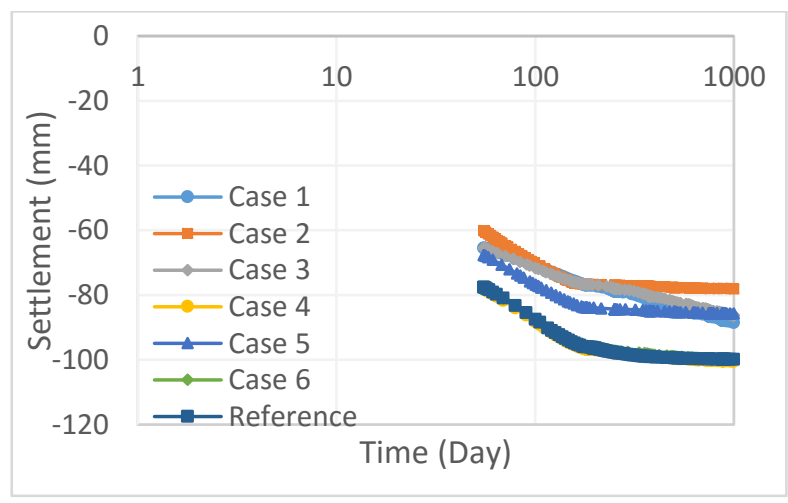


Figure 5. Settlement on the surface of embankment according to for different cases.

\subsubsection{Pressure acting on pile and subsoil}

Pressure acting over pile and subsoil is quite important to understand if the soil arching are formed or not. Calculated pressures at this pressure gauges can be seen on Figure 6. Pressures calculated for E4 and $\mathrm{E} 5$ are $39.2 \mathrm{kPa}$ and $32.7 \mathrm{kPa}$ for the reference case. As it can be seen from the figure, lower than reference case are calculated for E4 and E5. The highest pressure acting over the pile is calculated as $773.41 \mathrm{kPa}$ for the third case. Lowest pressure for E4 and E5 is calculated for third case also, which means better load transfer occurred for the third case.

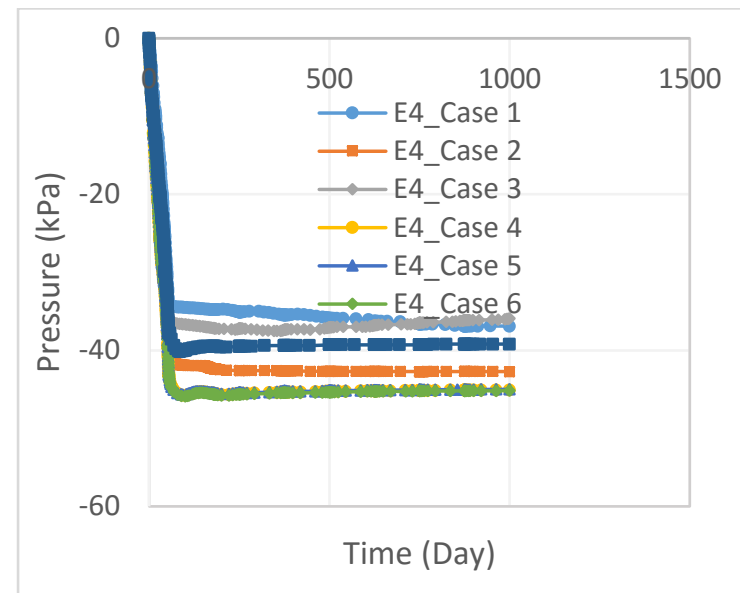

(a)

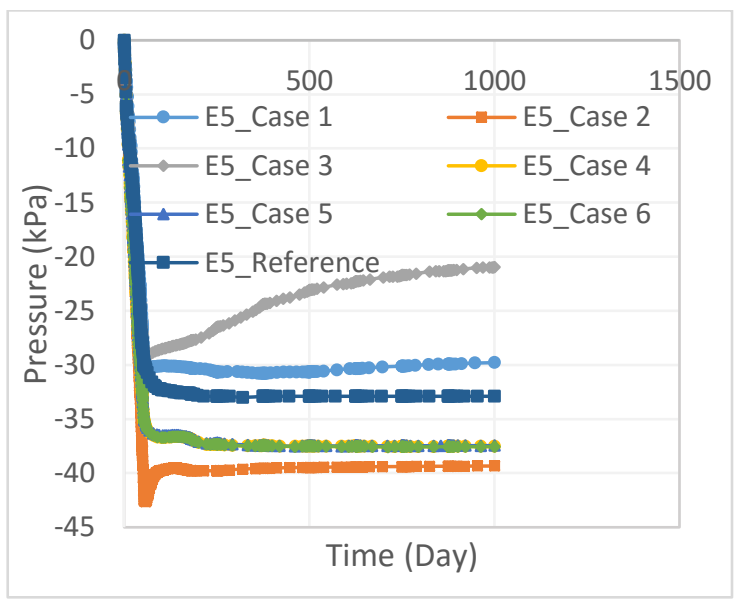

(b)

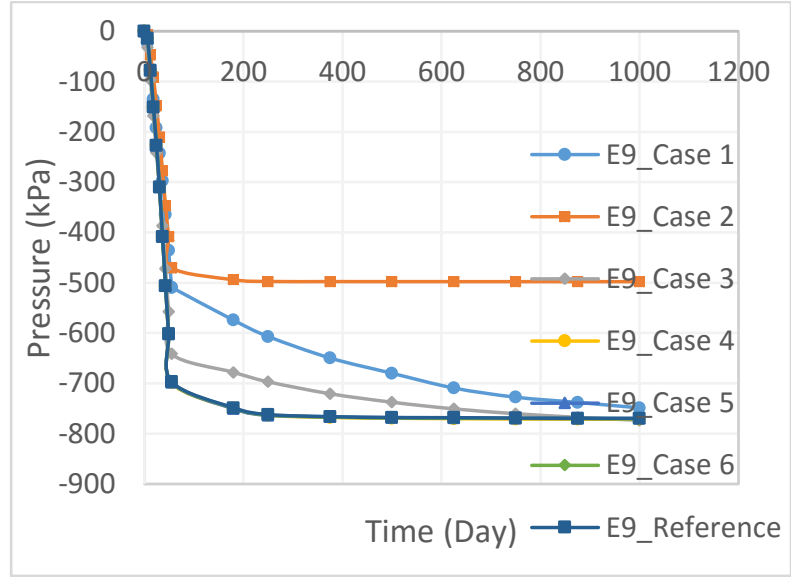

(c)

Figure 6. Calculated pressures on the gauges for two-layer reinforcement: (a) E4, (b) E5, (c) E9

\subsubsection{Excess pore water change}

Excess pore water pressure increases in reference case and other cases. Duration of excess pore water pressure increase is equal to the construction period of the embankment which is 55 days. After construction of embankment, excess pore water pressure tends to decrease and dissipate for all cases. However, the rate of dissipation differs for each case. Change of excess pore water pressure with time is displayed in Figure 7.

Excess pore water pressure for the reference case is calculated as $17.57 \mathrm{kPa}$ at the point PP2. Dissipation takes 354 days. Excess pore water pressure is calculated as $26.95 \mathrm{kPa}$ in case 1. Excess pore water pressure for the two-layer geosynthetic is calculated as $16.54 \mathrm{kPa}$ and dissipation takes 284 days for 
Balaban and Onur / Anadolu Univ. J. of Sci. and Technology A-Appl. Sci. and Eng. 19(2)-2018

case 2 . It should also be said that, for the cases 4,5 and 6 , excess pore water pressure is approximately $17.7 \mathrm{kPa}$.

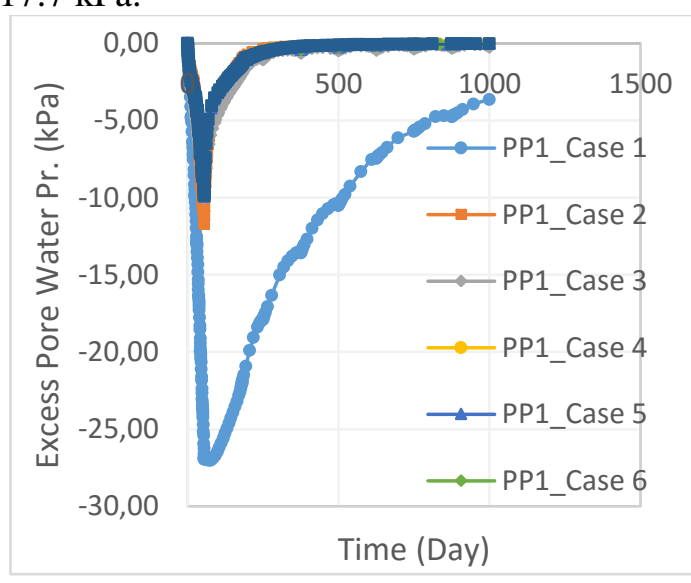

(a)

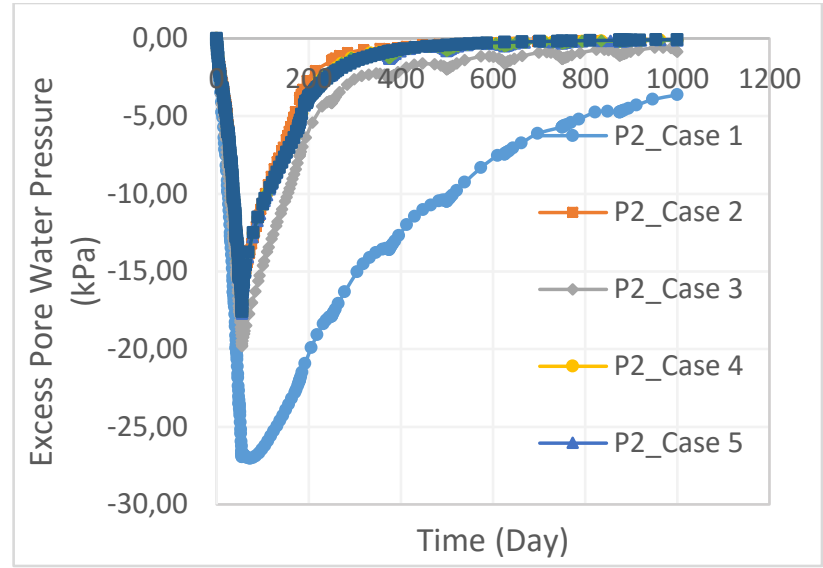

(b)

Figure 7. Change of pore water pressure with time for two-layer reinforcement: (a) PP1, (b) PP2.

\subsubsection{Horizontal displacement}

Horizontal displacements are calculated $1.5 \mathrm{~m}$ away from toe of embankment. Horizontal displacements are also calculated in every 5 meters starting from surface. It is seen that, in every case horizontal displacement decreases with depth of soil. Change of horizontal deformation can be seen in Figure 8 . Horizontal deformation calculated for the reference case equals to $39.43 \mathrm{~mm}, 32.86 \mathrm{~mm}, 19.42 \mathrm{~mm}$ and $4.43 \mathrm{~mm}$ for surface, $-5 \mathrm{~m},-10 \mathrm{~m}$ and $-15 \mathrm{~m}$ depths respectively. The lowest horizontal displacement on the surface is calculated as $38.97 \mathrm{~mm}$ for case 4 . However, for the depth of $-5 \mathrm{~m}$ and $-10 \mathrm{~m}$, the lowest displacement is calculated as $31.99 \mathrm{~mm}$ and $18.98 \mathrm{~mm}$ respectively for case 2 .

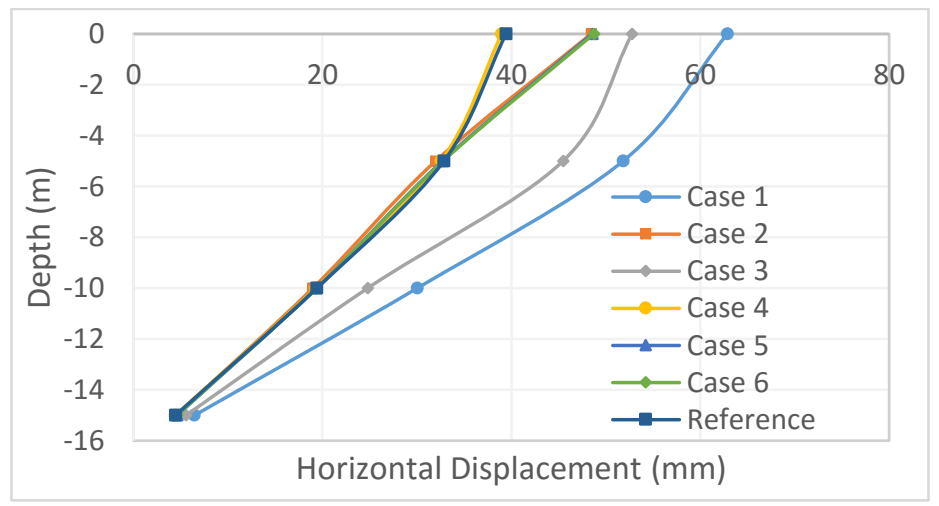

Figure 8. Change of horizontal deformation with depth for two-layer reinforcement

\subsection{Effect of 3 layer reinforcement}

Effects of using 3-layer reinforcement in the embankment are evaluated in this section. Five different cases were investigated for 3-layer of reinforcement.

\subsubsection{Settlements}

The lowest settlements are calculated for different cases for different settlement gauges. However, the highest settlements were always calculated for the fifth case. Calculated lowest settlements for S1, S2, 
$\mathrm{S} 3$ and $\mathrm{S} 4$ are $21.47 \mathrm{~mm}, 48.39 \mathrm{~mm}, 74.95 \mathrm{~mm}$ and $27.47 \mathrm{~mm}$ respectively. Settlements calculated for S1, $\mathrm{S} 2, \mathrm{~S} 3$ and S4 are displayed in Figure 9.

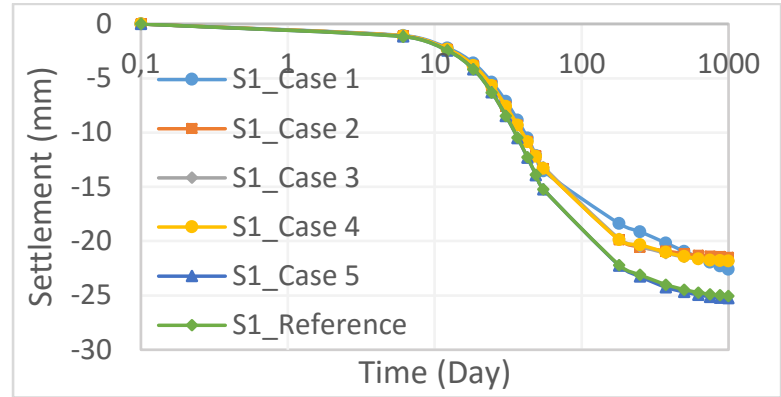

(a)

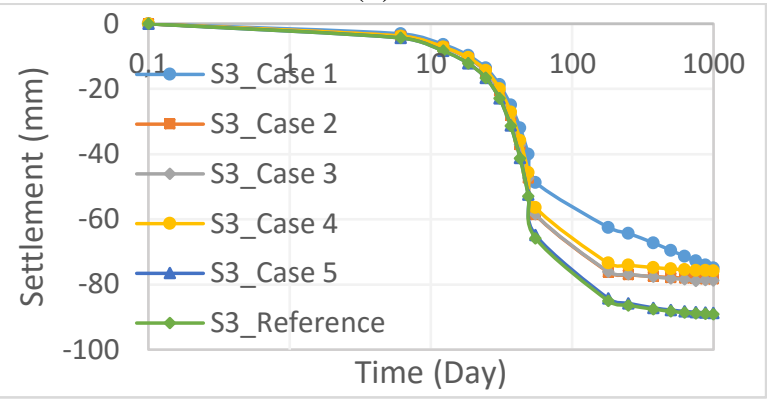

(c)

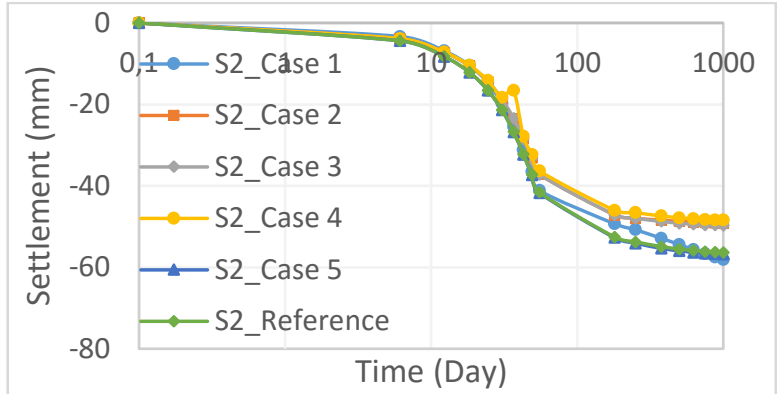

(b)

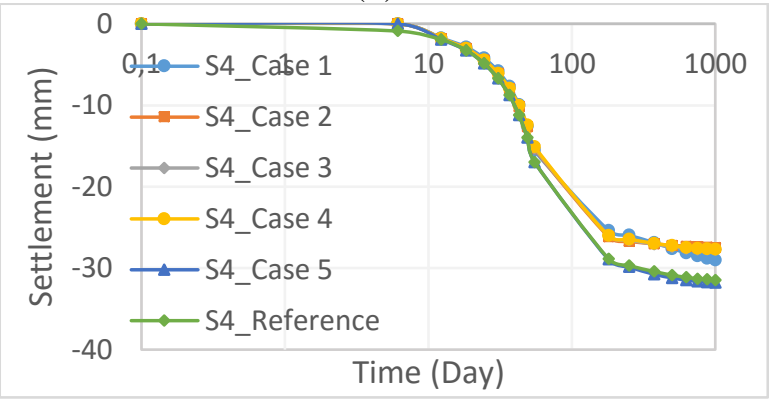

(d)

Figure 9. Calculated settlements for three-layer reinforcement: (a) S1, (b) S2, (c) S3, (d)S4.

Settlement on a top of the embankment is also investigated in this section. It is seen that lowest settlement is calculated as $85.11 \mathrm{~mm}$ on case 1, while highest settlement is calculated as $101.09 \mathrm{~mm}$ on case 5. Change of surface settlement with time is displayed in Figure 10. Comparison of lowest settlement and reference case yields reduction on settlement of $14.74 \%$.

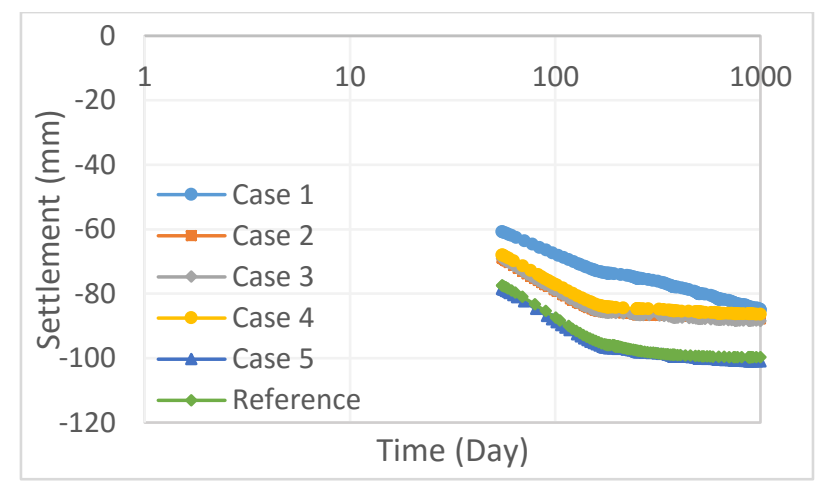

Figure 10. Embankment surface settlements varying with time for three-layer reinforcement

\subsubsection{Pressure acting on pile and subsoil}

The pressure is found to be lowest for case 1 while it is the highest for case 5 . Development of pressure on E4, E5 and E9 is shown in Figure 11 for all cases and reference case. Lowest pressure is calculated as $726.09 \mathrm{kPa}$ while highest pressure is calculated as $771.41 \mathrm{kPa}$. It can also be seen from the figure, pressure calculated on case 5 is slightly higher than reference case. 
Balaban and Onur / Anadolu Univ. J. of Sci. and Technology A-Appl. Sci. and Eng. 19(2) - 2018

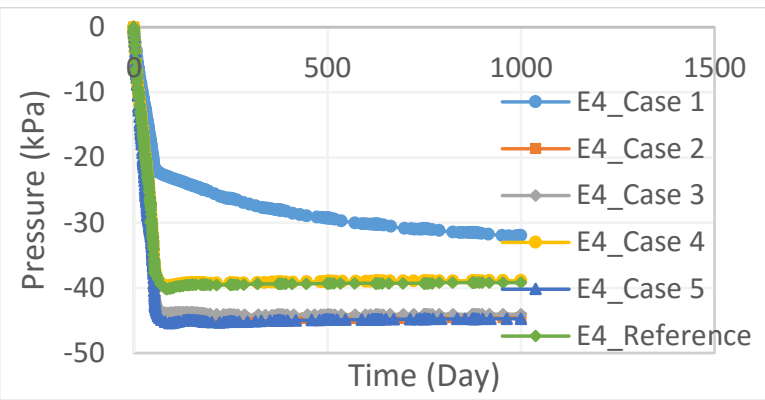

(a)

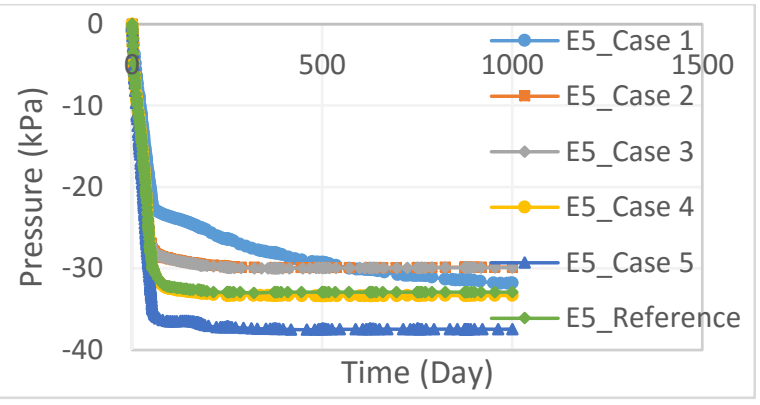

(b)

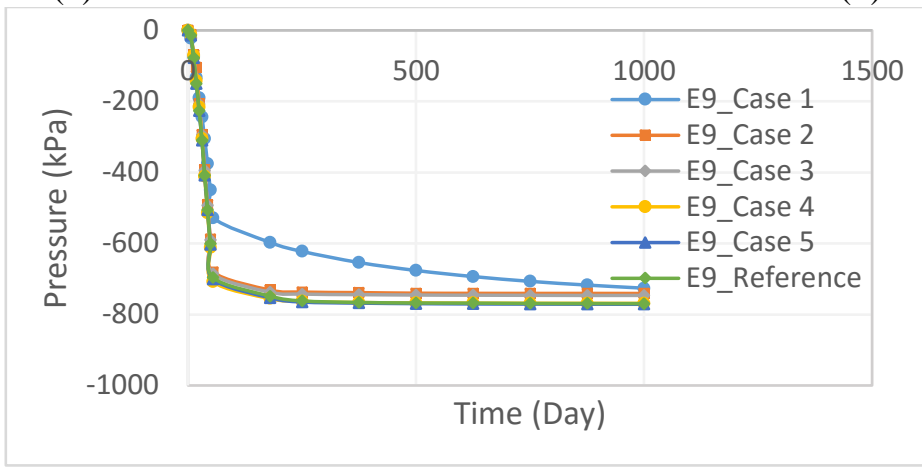

(c)

Figure 11. Calculated pressures for three-layer reinforcement: (a) E4, (b) E5, (c) E9

\subsubsection{Excess pore water behavior}

Highest excess pore water pressure is calculated for case 1 as $28.91 \mathrm{kPa}$ and $26.13 \mathrm{kPa}$ respectively. On the other cases except case 5, calculated excess pore water pressures at PP1 and PP2 are around $8 \mathrm{kPa}$ and $15 \mathrm{kPa}$. For the fifth case, calculated excess pore pressure at PP1 and PP2 are found to be $9.99 \mathrm{kPa}$ and $17.82 \mathrm{kPa}$ which are slightly higher than reference case. The development and dissipation of excess pore water pressure are shown in Figure 12.

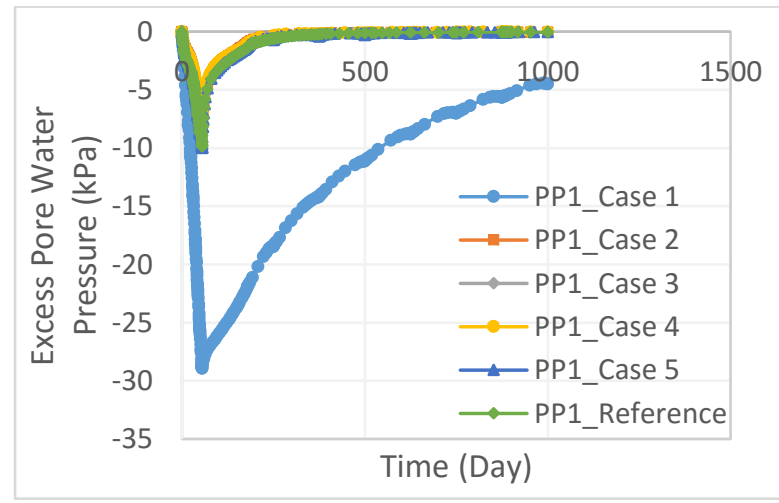

(a)

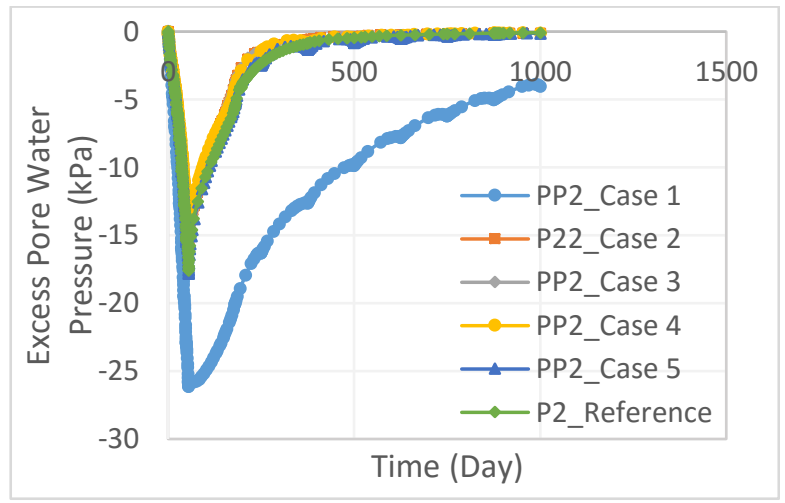

(b)

Figure 12. Change of pore water pressure with time for three-layer reinforcement: (a) PP1, (b) PP2.

\subsubsection{Horizontal displacement}

It is seen that, displacement calculated on soil surface is higher than reference for all cases considered for three-layer reinforcement. However, as the depth increases, calculated horizontal displacements decreases and get closer to reference case. Calculated horizontal displacements with depth can be seen in Figure 13. It can also be said that, as time passes, calculated deformations get lower. 


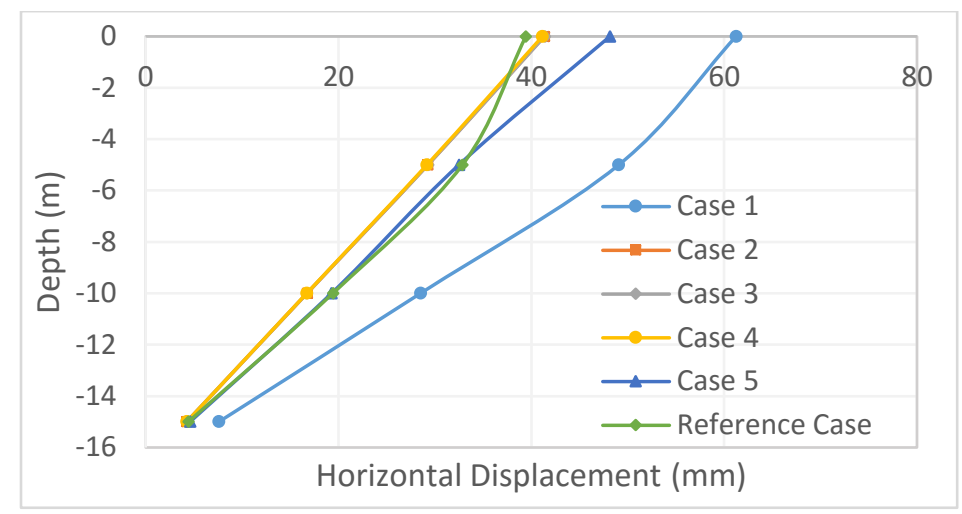

Figure 13. Calculated horizontal displacement for three-layer reinforcement

\section{DISCUSSION}

The findings of this study can be summarized as below.

- Settlements calculated for reference case are equal to $25.03 \mathrm{~mm}, 56.33 \mathrm{~mm}, 89.14 \mathrm{~mm}$ and $31.44 \mathrm{~mm}$ for S1, S2, S3 and S4 respectively. The lowest settlements are calculated as 20.80 $\mathrm{mm}, 48.06 \mathrm{~mm}, 73.29 \mathrm{~mm}$ and $26.50 \mathrm{~mm}$ for two-layer reinforcement for S1, S2, S3 and S4. In case of three-layer reinforcement, the lowest settlements are computed as $21.47 \mathrm{~mm}, 48.39 \mathrm{~mm}$, $74.95 \mathrm{~mm}$ and $27.47 \mathrm{~mm}$ on S1, S2, S3 and S4 points respectively.

- The lowest pressure on E4 point is calculated as $35.90 \mathrm{kPa}$ and $31.99 \mathrm{kPa}$ for two and threelayer cases respectively. However, the lowest pressure on E5 computed for two-layer and three reinforcements as $20.96 \mathrm{kPa}$ and $29.83 \mathrm{kPa}$ respectively. The highest pressure for E9 is computed for two-layer reinforcement and three-layer reinforcement cases as 773.41 and 771.41 $\mathrm{kPa}$ respectively. Computed pressures for the reference case are equal to $39.2 \mathrm{kPa}, 32.9 \mathrm{kPa}$ and $769.52 \mathrm{kPa}$ for E4, E5 and E9 respectively.

- The lowest excess pore water pressures on PP1 and PP2 are computed as $8.11 \mathrm{kPa}$ and 15.28 $\mathrm{kPa}$ respectively for two-layer reinforcement. It should be noted here that, excess pore water pressures calculated as $9.85 \mathrm{kPa}$ and $17.57 \mathrm{kPa}$ at PP1 and PP2 for three-layer reinforcement respectively.

- The lowest lateral displacement is calculated as $35.84 \mathrm{~mm}$ for two-layer reinforcement at the end of finite element analysis. In case of three-layer reinforcement, the lowest lateral displacement is computed as $37.66 \mathrm{~mm}$. Those values are computed at the end of finite element simulation at the surface natural soil and 1.5 meter away from embankment toe. Lateral displacement is calculated as $36.58 \mathrm{~mm}$ in case of the reference case at the same point.

\section{CONCLUSION}

In this study, effect of second and third layer of reinforcement were investigated by using finite element method. Firstly, a reference study was selected from literature. Once the acceptable results are calculated by finite element method then, parametric study is conducted regarding, settlement and pressures. Pore water pressures and lateral displacement of embankment are also included in the study.

Calculated settlements are significantly decreased in both two-layer reinforcement and three-layer reinforcement. Settlement of the embankment surface is also reduced significantly with an additional reinforcement. It is also seen that settlements tend to increase as the reinforcements are placed on the upper part of the embankment. 
From the results, it can be concluded that, additional number of reinforcement does not have significant effect on the calculated pressure both on soil and pile. This behavior can be explained as, reinforcement does not carry any load itself but distributes inside the embankment and transfer to the piles.

Excess pore water pressure can only dissipate from the surface due to drainage conditions. When the additional reinforcement is placed between embankment and natural soil, excess pore water pressure increases significantly at PP1 and PP2. Because, reinforcement tends to block the drainage to surface which also causes more time for dissipation of excess pore water pressure.

The excess pore water pressure increases dramatically when the first layer of reinforcement is placed between soil and embankment. However, in other cases, developed excess pore water pressure is slightly higher than the reference case.

It is also found out that, inclusion of additional reinforcement increases calculated horizontal displacement. However, horizontal displacement decreases as the depth of calculation increases.

\section{REFERENCES}

[1] Terzaghi K, Theoretical Soil Mechanics. 1th ed. New York, USA: John Wiley and Sons, Inc., 1943.

[2] Han J, Gabr MA. Numerical analysis of geosynthetic-reinforced and pile-supported earth platforms over soft soil. J. Geotech. Geoenviron. Eng 2002; 128: 44-53.

[3] Van Eekelen SJM, Bezuijen A, Lodder HJ, van Tol AF. Model experiments on piled embankments. Part I. Geotext. Geomembr 2012; 32: 69-81.

[4] Van Eekelen SJM, Bezuijen A, Lodder HJ, van Tol AF. Model experiments on piled embankments. Part II. Geotext. Geomembr 2012; 32: 82-94.

[5] Bhasi A, Rajagopal K. Numerical study of basal reinforced embankments supported on floating/end bearing piles considering pile - soil interaction. Geotext. Geomembr 2015; 43: 524-536.

[6] Lai H, Zheng J, Zhang J, Zhang R, Cui L. DEM analysis of "soil"-arching within geogrid-reinforced and unreinforced pile-supported embankments. Comput. Geotech 2014; 61: 13-23.

[7] Xing H, Zhang Z, Liu H, Wei H. Large-scale tests of pile-supported earth platform with and without geogrid. Geotext. Geomembr 2014; 42: 586-598.

[8] Huang J, Han J. Two-dimensional parametric study of geosynthetic-reinforced column-supported embankments by coupled hydraulic and mechanical modeling. Comput. Geotech 2010; 37: 638-648.

[9] Huang J, Han J. 3D coupled mechanical and hydraulic modeling of a geosynthetic-reinforced deep mixed column-supported embankment. Geotext. Geomembr 2009; 27: 272-280.

[10] Zhang J, Zheng J, Chen B, Yin J. Coupled mechanical and hydraulic modeling of a geosyntheticreinforced and pile-supported embankment. Comput. Geotech 2013; 52: 28-37.

[11] Liu KW, Rowe RK. Performance of reinforced, DMM column-supported embankment considering reinforcement viscosity and subsoil's decreasing hydraulic conductivity. Comput. Geotech 2016; 71: $147-158$.

[12] Zhang L, Zhao M, Hu Y, Zhao H, Chen B. Semi-analytical solutions for geosynthetic-reinforced and pile-supported embankment. Comput. Geotech 2012; 44: 167-175. 
[13] Ariyarathne P, Liyanapathirana DS. Review of existing design methods for geosynthetic-reinforced pile-supported embankments. Soils Found 2015; 55: 17-34.

[14] Lu WH, Miao LC. A simplified 2-D evaluation method of the arching effect for geosyntheticreinforced and pile-supported embankments. Comput. Geotech 2015; 65: 97-103.

[15] Ghosh B, Fatahi B, Khabbaz H. Mechanical model to analyse multilayer geosynthetic reinforced granular layer in column supported embankments. Procedia Eng 2016; 143: 387-394.

[16] Lehn J, Moormann C, Aschrafi J. Numerical investigations on the load distribution over the geogrid of a basal reinforced piled embankment under cyclic loading. Procedia Eng 2016; 143: 435-444.

[17] Van Eekelen SJM. The 2016-update of the Dutch design guideline for basal reinforced piled embankments. Procedia Eng 2016; 143: 582-589.

[18] Van Eekelen SJM, Venmans AAM. Piled embankment or a traditional sand construction: how to decide? a case study. Procedia Eng 2016; 143: 590-597.

[19] Zhou W, Lao J, Huang Y, Chen R. Three-dimensional finite element modelling of soil arching in pile-supported geogrid-reinforced embankments. Procedia Eng 2016; 143: 607-614.

[20] Liu H, Ng CW, Fei K. Performance of a geogrid-reinforced and pile-supported highway embankment over soft clay: case study. J. Geotech. Geoenviron. Eng 2007; 133: 1483-1493.

[21] Rui R, Van Tol AF, Xia YY, Van Eekelen SJM, Hu G. Investigation of soil-arching development in dense sand by $2 \mathrm{~d}$ model tests. Geotech. Test. J 2016; 39: 415-430.

[22] Van Eekelen SJM, Bezuijen A, Van Tol AF. Analysis and modification of the British Standard BS8006 for the design of piled embankments. Geotext. Geomembr 2011; 29: 345-359.

[23] Rui R, Van Tol F, Xia XL, Van Eekelen SJM, Hu G, Xia YY. Evolution of soil arching; 2D DEM simulations. Comput. Geotech 2016; 73: 199-209.

[24] Rui R, Van Tol F, Xia YY, Van Eekelen, SJM, Hu G. Evolution of Soil Arching: 2D Analytical Models. Int. J. Geomech 2018; 18: 04018056.

[25] Van Eekelen SJM, Bezuijen A, Van Tol AF. Validation of analytical models for the design of basal reinforced piled embankments. Geotext. Geomembr 2015; 43: 56-81.

[26] Das BM, Sobhan K. Principles of Geotechnical Engineering. 8th ed. Stamford, CT, USA: Cengage Learning, 2012.

[27] Mohamed SBA, Yang, KH, Hung WY. Finite element analysis of two tier geosynthetic - reinforced soil walls: comparison involving centrifuge tests and limit equilibrium results. Comput. Geotech 2014; 61: 67-84.

[28] Brinkgreve RB, Vermeer PA. Plaxis Ver. 7.2 Manual Finite Element Code for Soil And Rock Analyses, Hollanda: Balkema, 1998.

[29] Sturr S. Determination of Soil Stiffness Parameters. Lecture Notes of Short Course on Computation Geotechnics + Dynamics. Boulder Colorado, 2004. 